\title{
$\begin{array}{lllllllll}S & \mathrm{Y} & \mathrm{M} & \mathrm{P} & \mathrm{O} & \mathrm{S} & \mathrm{I} & \mathrm{U} & \mathrm{M}\end{array}$
}

\section{CIVIC WEALTH CREATION: A NEW VIEW OF STAKEHOLDER ENGAGEMENT AND SOCIETAL IMPACT}

\author{
G. T. LUMPKIN \\ University of Oklahoma \\ SOPHIE BACQ \\ Indiana University
}

\begin{abstract}
Positive societal change happens when community members, supporters, and entrepreneurially minded agents come together to aggregate resources and build new capacities. To explain and inform how societal impact happens across categories of stakeholders, we set forth an integrative framework of civic wealth creation to account for the social, economic, and communal endowments generated by local communities. Our framework shifts the conversation to a "civic" level of analysis that captures the variety of local settings where many societal change initiatives take place-in neighborhoods, villages, and communities where the people who are being helped are intimately involved in creating and implementing the solutions. Civic wealth extends beyond the material resources and physical assets of a community to include intangibles such as health, happiness, and social justice. We draw attention to the importance of citizen engagement and entrepreneurial commerce in the discourse surrounding contemporary societal change efforts. The civic wealth creation framework offers scholars and practitioners across disciplines a new lens through which to view societal impact.
\end{abstract}

This article is the outcome of a truly collaborative effort, and both authors contributed equally. We would like to thank editor Gideon Markman for his exceptional guidance and two anonymous reviewers for their developmental and thoughtful feedback. We are thankful to all of those who graciously provided advice and shared concerns on previous versions of this manuscript: Alejandro Amezcua, Mattia Anesa, Julie Battilana, Andrew Corbett, Justin Craig, Silvia Dorado, R. Edward Freeman, Jooho Lee, Benyamin Lichtenstein, Jeffery McMullen, Danny Miller, Abhisekh Ghosh Moulick, Sunny Sanwar, Trenton Williams, and participants in the annual Social Entrepreneurship Doctoral Seminar (2012-2017). This work also benefited greatly from discussions that followed presentations at Syracuse University, the University of Western Ontario, and the Satter Social Entrepreneurship Conference in 2012, Rutgers University and the Duke/ Oxford Research Colloquium on Social Entrepreneurship in 2013, the GW Global Entrepreneurship Conference, IE Business School, and Bocconi University in 2014, the University of Queensland and the University of Oklahoma in 2015, and the Academy of Management annual meeting in 2016.
Achieving societal impact and catalyzing societal change are important drivers for nonprofits and social innovators, socially minded start-ups and major corporations, and every level of government (Chliova \& Ringov, 2017; Dacin, Dacin, \& Matear, 2010). Across all of these domains, on issues as vast as poverty, homelessness, educational inequality, social injustice, lack of access to health care, and environmental degradation, the core question is this: "How can we create positive societal change and sustainable impact?"

Research suggests that the involvement of multiple stakeholders in societal change initiatives, often across sectors, is vital to success (Bryson, Crosby, \& Stone, 2006; Lichterman \& Eliasoph, 2014). Three main stakeholder categories make critical contributions to societal change efforts. The first is beneficiaries themselves, members of the communities where the societal change initiative is taking place. Unless the people and the cultures that are the focus of the change are engaged, the impact of external supporters has been found to be temporary, 
one-sided, or even harmful (Lupton, 2012; Moyo, 2009). When initiatives begin within their community settings, however, societal impact tends to be relatively stronger (Tracey, Phillips, \& Haugh, 2005).

Second, to catalyze societal change initiatives, supporters such as donors, corporations, social service organizations, governments, and other regimes of support provide financial, technical, and political assistance. Third, research suggests that lasting societal change is catalyzed by starting enterprises. This is the promise of social entrepreneurship (Dees, 1998; Mair \& Martí, 2006) and environmental entrepreneurship (Dean \& McMullen, 2007; York, O’Neil, \& Sarasvathy, 2016), which have grown in importance because they focus on benefiting communities through income generation and sustainable solutions. Thus, positive societal impact is achieved when three key actors-Community, Regimes of Support, and Enterprise-purposefully collaborate, highlighting the importance of studying societal change initiatives at the local level.

In this paper, we propose a "civic" level of analysis, a context that parsimoniously captures the variety of settings where many societal change initiatives take place and draws attention to the importance of citizen engagement and entrepreneurial commerce in bringing about change. Civic-level impact is achieved locally-in neighborhoods, villages, and communities where the people who are being helped are intimately involved in creating and implementing the solutions. The result of such initiatives, when successful, is civic wealth creation (CWC)—defined as the generation of social, economic, and communal endowments that benefit local communities. The purpose of this paper is to set forth a framework for understanding civic wealth creation, and to address these questions: What is civic wealth, and how is it created?

This analysis stands to make several contributions to societal impact research and practice. First, the extra-organizational nature of CWC addresses recent calls to move beyond the assumptions of an organizational level of analysis (Shepherd, 2015) when studying societal impact. By shifting the conversation about impact to a civic level of analysis, a CWC perspective highlights the relevance of the community as a context for social action and the role of local citizenry in bringing about change (Berrone, Gelabert, Massa-Saluzzo, \& Rousseau, 2016; Lumpkin, Bacq, \& Pidduck, 2018). It also reflects the Academy of Management's original aspiration to serve the public interest not only through individual and organizational research but also through societal-level scholarship (George, Howard-Grenville, Joshi, \& Tihanyi, 2016; Walsh, Weber, \& Margolis, 2003).

Second, the CWC concept embraces an appreciation for "wealth" beyond money and material possessions. In contrast to narrower conceptualizations of wealth that do not capture the range of outcomes that many societal change initiatives aim to achieve, civic wealth represents a blend of material benefits with intangible, nonpecuniary forms of wealth.

Third, the CWC framework draws attention to the intentionality involved in bringing about positive societal change or maintaining the civic vibrancy of a community. Whereas market forces that favor a community may contribute to its overall well-being, such progress may be fleeting-changes in technology, depletion of natural resources, or the lure of higher profits elsewhere may deprive a community of its wealth. When that happens, maintaining community well-being may be beyond the reach of the public sector or government action. CWC reflects the intentionality (Haugh, 2007) that is required to create or restore a community's social, economic, and communal standing when governments and/or market forces are insufficient.

Fourth, to address the purposeful actions involved in setting and achieving civic-level outcomes, we employ a novel application of stakeholder theory. Building on insights from the principle of stakeholder cooperation (Freeman, Harrison, Wicks, Parmar, \& De Colle, 2010), we apply instrumental stakeholder perspectives (Donaldson \& Preston, 1995; Van de Ven \& Poole, 1995) to address how communities with common goals create civic wealth through the interaction of multiple stakeholders with diverse but joint interests. To help frame our arguments, we begin with examples of successful CWC.

\section{EXAMPLES OF CIVIC WEALTH CREATION}

CWC represents a comprehensive approach to understanding the impact of a broad category of societal change efforts. As the examples below illustrate, CWC encompasses four characteristics that together provide a holistic perspective on societal change: 1) a civic level of analysis that zeroes in on a populace or defined community as the locus of societal change; 2) the importance of engaging a wide array of stakeholders, including the citizens who benefit from the civic-level change; 3 ) the role of entrepreneurial commerce in funding and sustaining societal change solutions; and 4) a perspective toward wealth that goes beyond economic interests to 
also include social and communal wealth, where social wealth reflects the benefits (e.g., improved access to health care, education, justice, etc.) accruing to the well-being of a community that embraces the contributions of its supporters, and communal wealth is created out of a community's entrepreneurial efforts to build capacity, enrich culture, and enhance self-sufficiency.

The Mondragón Corporation, ${ }^{1}$ a federation of worker cooperatives located in Spain's Basque region, employs more than 80,000 employees, making it one of the largest Spanish corporations. Yet at the very core of Mondragón-whose motto is "Humanity at work"-lies human and professional development of its workers through job creation, as well as community-level social responsibility. As cooperative members, workers are directly engaged, along with thousands of nonmember employees and capital providers, in developing and supporting the civic wealth of the region. Entrepreneurial commerce is essential to Mondragón's sustainability, which operates sales and production facilities on five continents. But Mondragón's wealth creation goes well beyond its impressive financial returns (more than $€ 12$ billion in 2016). In addition to its founding motives at inception-rebuilding the regional economy destroyed by the Spanish Civil War and the Second World War-Mondragón has also generated social wealth by providing full health care coverage and services for employees and communities, as well as communal wealth through community engagement in various enterprises and cultural movements that have built and maintained social cohesion for generations (Defourny \& Develtere, 2009).

Housing Works, ${ }^{2}$ a community-based AIDS service organization in the United States, provides housing, primary care, job training, and legal help to more than 20,000 homeless and low-income New Yorkers living with HIV/AIDS. Housing Works engages the community broadly: It benefits from New York's art community when it comes to donations, and also involves artists, collectors, educators, and curators as customers in its bookstore café, where homeless and low-income citizens are trained and employed. The intersection of books and food has proven to be an effective way to build communal wealth by engaging the community in making its lifesaving services more sustainable. The sale of secondhand books, coffee, beer, and pastries directly generates funds to

\footnotetext{
${ }^{1}$ See www.mondragon-corporation.com.

${ }^{2}$ See www.housingworks.org.
}

support social wealth creation in the form of primary care and housing. Since its inception, the bookstore community space has also evolved into a cultural institution where knowledge and culture are shared.

Water for People ${ }^{3}$ is a nongovernmental organization (NGO) that involves impoverished villagers in developing their own sustainable water and sanitation systems. Combined with a hygiene education program, its approach engages every member of the community-including local entrepreneurs and civic leaders, parent associations and school administrators, and local government and development organizations-in building hand-washing stations and toilet facilities in targeted schools. Solutions are never merely handed out to the community; rather, community members invest their labor, skills, and money to realize them. Such a focus on community ownership not only ensures that good hygiene practices learned in schools are reinforced at home by parents, but also improves the chances that the system will be financially viable and sustainable. By providing hygiene education along with access to sanitation infrastructure, the NGO creates social wealth in terms of improving general health against water-borne diseases. Further, the empowerment of the community members who invest in, develop, and own the water and sanitation infrastructure generates communal wealth in terms of a locally managed self-sustaining system and a heightened sense of dignity.

These examples, and many other communityoriented societal impact cases, illustrate the four distinguishing features of CWC mentioned above.

\section{A Civic Level of Analysis}

Many societal change efforts are not at the organizational level but are extra-organizational; that is, they take place in neighborhoods, villages, and communities and among networks of people whose shared experience creates a common bond, as recently highlighted in the literature (e.g., Dubb, 2016; Lumpkin et al., 2018; Shepherd \& Williams, 2014). These settings are represented by the word civic, which captures the variety of community-oriented locales that are the focus of many societal change initiatives. The term civic also draws attention to the role of local participation, and to a sense of responsibility for others that goes beyond strictly economic considerations.

\footnotetext{
${ }^{3}$ See www.waterforpeople.org.
} 


\section{Engaging a Wide Array of Stakeholders}

The initiatives arising in these extra-organizational ecosystems involve community members and multiple stakeholders coalescing to achieve mutually beneficial goals (Longhofer, Negro, \& Roberts, 2019). Citizens from the communities being helped are not just beneficiaries but essential participants in problem solving and enterprise development because of their role in generating support and knowledge of local conditions. This aspect highlights the parallels between CWC and Ostrom's (1990) research, which found that under the right conditions, self-organized and self-governing collective actions by small, cohesive groups can generate feasible solutions to formidable social and environmental problems.

\section{Entrepreneurial Commerce to Fund and Sustain Societal Change}

CWC solutions distinguish themselves by relying on entrepreneurial commerce to produce positive societal change. Entrepreneurial action-proactively finding and creatively implementing financially viable solutions in settings where competing interests and constrained resources demand innovative thinking (McMullen \& Dimov, 2013; Ostrom, 1965)—is often critical for advancing and sustaining societal change. It contributes to self-sufficiency and tends to enhance efforts to build legitimacy and attract resources.

\section{A Perspective Toward Wealth That Goes Beyond Economic Interests}

Civic-level change initiatives produce social wealth by engaging citizens, developing capabilities, and enhancing quality of life; they create economic wealth through productive commerce and efficient use of resources; and they generate communal wealth by building local capacity and self-sufficiency and elevating culture (Alvord, Brown, \& Letts, 2004; Haugh, 2005). These factors suggest a "total wealth" perspective that accounts for the tangible dimensions (e.g., products, clients served, material gains) and intangible dimensions (e.g., health, happiness, social justice) of wealth creation (Zahra, Gedajlovic, Neubaum, \& Shulman, 2009).

Taken together, these examples suggest the idea of civic wealth creation, a term that captures the local flavor of many positive societal change efforts, and extends Zahra and colleagues' (2009) notion of total wealth as the combination of social and economic outcomes. The civic wealth concept is a comprehensive indicator of the intellectual, affective, and material resources, capacities, and capabilities of a civic unit of analysis.

The purpose of this paper is to elaborate on what CWC consists of and theorize about how multiple stakeholders with joint interests create civic wealth. By focusing on wealth creation and shifting attention to a civic level of analysis, a CWC perspective extends our understanding of how societal impact is achieved. As our conceptual framework will demonstrate, it holistically accounts for the interactions of the three major sectors of society-private (business), public (government), and civil (often referred to as the third sector).

\section{A STAKEHOLDER APPROACH TO CREATING CIVIC WEALTH}

Shifting attention to a civic level of analysis highlights an important feature of societal change initiatives, namely the wide array of stakeholders involved in generating positive societal change. At the civic level, multiple types of stakeholders with varying motivations are seeking common ground on which to benefit society and also enjoy mutual benefits (e.g., Berrone et al., 2016; Fowler, 2000). As such, stakeholder theory provides valuable insights for elucidating situations where multiple actors with different perspectives productively interact in the interest of CWC. Consistent with Phillips, Freeman, and Wicks (2003), we depart from a firm-centric view of stakeholder theory and apply it to civic settings consisting of extra-organizational coalitions, partnerships, cooperative ventures, and other arrangements involving multiple stakeholders, including those who are direct beneficiaries of societal change efforts. This application of stakeholder theory is consistent with research that has used it in community and public-sector contexts (Bryson, 2004; Friedman \& Mason, 2004) and recent analyses of stakeholder theory and social welfare (e.g., Bridoux \& Stoelhorst, 2016).

The CWC process begins once stakeholders coalesce around a specific goal that reflects their shared interests. As an engine of societal change, CWC is distinguished from other change processes by its intentionality (Van de Ven \& Poole, 1995). Whereas market forces can create economic wealth that brings about community improvements such as services for the poor, enhanced infrastructure, or cultural prosperity, these benefits are mostly by-products of profit seeking and may be temporary as shifts in market 
forces change fortunes. CWC, because it is aimed at strengthening and sustaining a focal civic setting, seeks economic and noneconomic benefits and endowments that are more lasting. In situations where jobs have been lost, neighborhoods have deteriorated, and support services are no longer available, CWC involves revitalization and community development. In areas that have never enjoyed economic prosperity, such as rural regions in developing countries, CWC involves finding support, welcoming interventions, and leveraging local resources. Even though CWC, like all creative processes, will ebb and flow as conditions change, it is achieved by intentional efforts to build and leverage social and communal endowments in addition to economic ones.

Civic wealth is created when a group of stakeholders voluntarily commits to making positive societal change through purposeful efforts. This suggests an instrumental approach consistent with Freeman and colleagues' principle of stakeholder cooperation, which states in part:

[S]takeholders can jointly satisfy their needs and desires by making voluntary agreements with each other that for the most part are kept. ... This principle highlights the social nature of value creation. ${ }^{4}$ Value is not "discovered" lying around in the market, but created through shared assumptions and beliefs in a community. ... We must create value in a context, with the help of others and with others who value what we create. (Freeman et al., 2010, p. 281)

Civic wealth creation exemplifies stakeholder cooperation. Stakeholders from three major categories join forces to create civic wealth. The first category is the Community, which refers to the focal civic setting where a societal problem is being addressed. The stakeholders are its members, those who are affecting and/or affected by the societal change. Second, a variety of agents and organizations provide financial backing, legal authority, administrative assistance, and other forms of aid in support of positive societal change. Depending on the context, this broad category of stakeholders-Regimes of Support-may include NGOs, philanthropic organizations, social venture funders, governments, universities, and even crowdfunders. Fruitful interactions leading to

\footnotetext{
${ }^{4}$ Although the term value creation is embedded in the language of stakeholder theory, we believe a wealth creation perspective more effectively reflects the local resources, cumulative endowments, and collective contributions of multiple parties suggested by CWC.
}

positive societal outcomes between Regimes of Support and Community have flourished historically in the context of traditional philanthropy. What makes CWC distinct is the third category, Enterprise, where business-oriented stakeholders with an eye for market opportunities and the ability to manage financially viable operations engage in entrepreneurial commerce. Adopting a three-circle model, we synthesize these interdependent categories in Figure 1, which depicts examples of stakeholders in each category.

Given such stakeholder diversity, in CWC contexts, the path to fruitful cooperation is often highly complex even when synergistic interactions are intentional (Alvord et al., 2004; Austin, Stevenson, \& Wei-Skillern, 2006). To address this complexity and elaborate on how civic wealth is created, we developed an integrative framework that explains how interactions among the three major categories of stakeholders generate wealth. We identify the logics underlying the stakeholder categories and propose that civic wealth is created when these logics interact.

\section{Civic Wealth Creation Stakeholders and Logics of Action}

Although there is heterogeneity within each stakeholder category, as Figure 1 reveals, Community, Regimes of Support, and Enterprise members each operate with certain underlying assumptions and beliefs that influence their decision-making processes and actions. Consistent with prior management and entrepreneurship research (Prahalad \& Bettis, 1986; Sarasvathy, 2001), we refer to these assumptions as logics, or "logics of action"-that is, "a range of goals, strategies and bases of evaluation” (Biggart \& Delbridge, 2004, p. 31).

Community. The Community category refers to the civic settings where societal change initiatives take place. Urban neighborhoods and remote villages are examples, as are communities or citizen groups defined by "shared geographical location, generally accompanied by collective culture and/or ethnicity” (Peredo \& Chrisman, 2006, p. 315). In such settings, there is a sense of identity that emerges from a shared history and a sense of belonging associated with physical space. But this stakeholder category can also refer to participants in a larger collective or networks of people where geography is not central, such as veterans with disabilities. Community members are those who face similar conditions and, because of shared experiences, enjoy a common 
FIGURE 1

Examples of Civic Wealth Creation Stakeholders

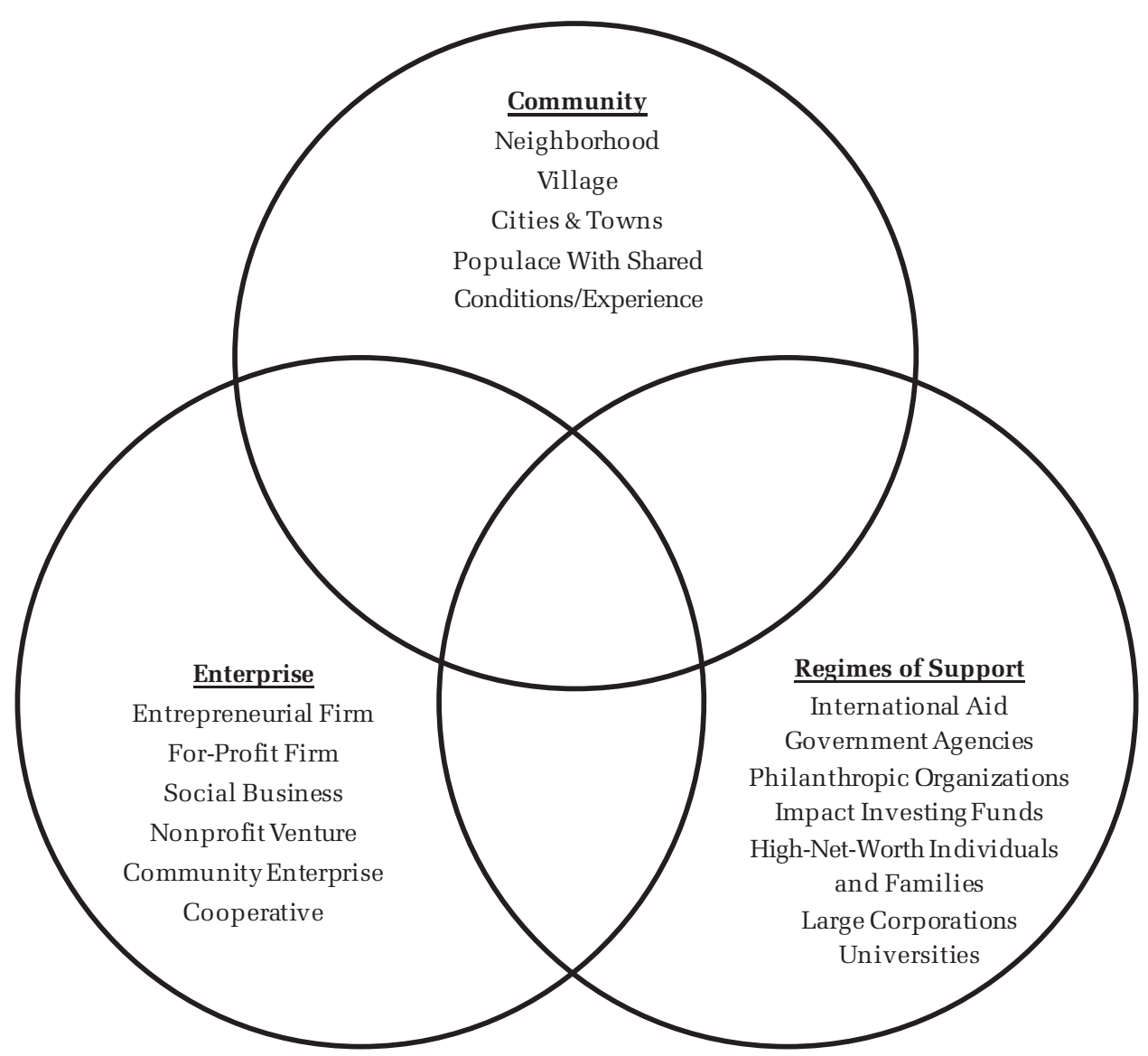

bond. Initially, however, they may lack intentionality and cohesiveness as a community. Often, it is not until an initiative-such as a community enterprise-spurs them into action that the character and beliefs of a community begin to shape aspirations and influence outcomes.

The intentionality underlying the Community stakeholder category stems from the logics of kinship and citizenry. Kinship refers generally to the affinity and sense of bonding that arises among people who are related and those who share similar characteristics, experiences, or interests, whether or not they are physically proximal (Holland, 2012; Stewart, 2003). Citizenry refers to the common bonds and shared responsibilities of those who live together in a community (Putnam, 2000). It implies both rights and duties, and can foster a sense of responsibility to participate in the community. Identification with a group with common experiences, history, or physical surroundings evokes feelings of cohesiveness (e.g., Young, Russell, \& Powers, 2004). Cohesion engenders perceptions of belonging that can spur the development of shared norms, values, and beliefs (Bollen \& Hoyle, 1990). Building on such cohesion, the logics of kinship and citizenry motivate efforts to benefit the community by leveraging the group's collective power to advance its well-being, care for its environment, or preserve a sense of identity and belonging. Relative to isolated members of society, communities and kin have strength in numbers to improve their conditions, raise living standards, sustain their environment, or bolster economic underpinnings. Hence, the logics of kinship and citizenry reflect local engagement-where "local" is an area that is bounded though not necessarily physically proximal-by members of a cohesive group with common aspirations to foster and sustain civic wealth.

Regimes of Support. The Regimes of Support category encompasses a broad array of stakeholders who provide essential resources and the authority to act in a civic setting. Supporters often have a strong 
influence on community activities, even if they are not involved in day-to-day operations. Support varies across different ecosystems and includes economic development initiatives advanced by international aid organizations, enabling legislation sponsored by elected officials, and so forth. Funding is a critical type of support that manifests differently depending on the context-from charitable support such as donations and grants to new approaches to funding such as impact investing and crowdfunding (Bugg-Levine, Kogut, \& Kulatilaka, 2012; Lehner \& Nicholls, 2014). Sources of funding can be private (philanthropic, corporate, impact investors, high-net-worth individuals or families) or public (governmental), and may, depending on their size, represent different levels of influence. An increasing number of corporations are also providing in-kind and other types of support such as volunteering programs that allow employees to dedicate work hours to helping societal change initiatives. Universities often provide research, facilities, and training support. The features of the civic context and the nature of the problems being addressed determine how supporters in this category influence outcomes.

Regimes of Support are animated by the logics of influence and control. Stakeholders in this category become involved because they want to influence societal change efforts. With the resources and authority they bring to the process, Regimes of Support can exert control over which issues will be prioritized and how missions will be advanced (Barman, 2008). Even highly benevolent support is often accompanied by mechanisms of control, such as board memberships that give supporters a voice in decision making or reporting requirements that enable them to monitor outcomes (Chisolm, 1995). Beyond control is the outwardly directed influence that supporters expend on behalf of societal initiatives by providing funding, leveraging social capital, and exercising legal authority (e.g., Austin et al., 2006). The logics of influence and control are essential to CWC because they add legitimacy (Stephan, Patterson, Kelly, \& Mair, 2016) and contribute to favorable public perceptions by affording oversight and a sense of order.

Enterprise. The Enterprise category refers to entrepreneurial ventures and initiatives aimed at generating revenue through market-based commerce. Different organizational forms may be employed to pursue a societal mission in a CWC context. For example, some social and environmental ventures are organized and operated as for-profit businesses that return a profit that is then used to expand societal impact rather than to pay dividends to owners (e.g., Dees \& Anderson, 2003; Yunus, 2008). The Enterprise category also includes low-profit organizations that dedicate a percentage of their returns to social causes (Marquis \& Park, 2014) and nonprofits that use entrepreneurial practices to enhance performance, an increasing trend (Gras \& MendozaAbarca, 2014). Community enterprises are another type that harness entrepreneurial activities under conditions of material poverty to engage in commercial activities such as farming (Peredo, 2003), selling crafts (Haugh, 2005), and development trusts (Stott, Fava, Tracey, \& Claus, 2018). Cooperatives such as the Mondragón Corporation are often known for their innovative practices and entrepreneurial mindset (Ellerman, 1984). Although the different legal forms of organizing may matter in a regulatory sense in constraining or enabling activities, this does not alter their basic function as purposive entities that are operated as financially viable enterprises.

Revenue-generating initiatives and ventures in the Enterprise category are driven by the logics of business and entrepreneurship. Entrepreneurial commerce is guided by norms of profitable exchange that are essential to financial viability, continuous improvement, and growth. The logic of business revolves around offering financially attractive value propositions that include selling goods or services at prices that exceed the costs of production (Zott \& Amit, 2007). Returns can be enhanced through strategic decision making, operational efficiencies, and management techniques that increase profitability (Eisenhardt \& Zbaracki, 1992). The logic of entrepreneurship involves identifying, developing, and exploiting opportunities; creating new goods and services; and launching financially viable and profitable new ventures (Fisher, 2012; McMullen \& Dimov, 2013; Shane \& Venkataraman, 2000).

\section{THE CIVIC WEALTH CREATION FRAMEWORK}

Civic wealth is created when multiple stakeholders with different logics join forces in collective actions that improve the welfare of a segment of society. In any given civic setting, the assemblage of stakeholders within each category represented in Figure 1 will vary. In one case, villagers may seek international aid and training to launch an enterprise to benefit the community (e.g., Water for People). In another case, social workers may persuade local community residents, artists, and activists to join forces to run a sustainable enterprise whose profits assist in funding the mission (e.g., Housing Works). 
Although there is heterogeneity within each stakeholder category, the type of wealth that is created when the different stakeholder logics interact is generally the same. In this section, we explicate these interactions to address how civic wealth is created.

\section{Wealth Creation at the Intersections of Community, Regimes of Support, and Enterprise}

Akin to the "multi-attribute utility functions" process used by Tantalo and Priem (2016) to outline mechanisms of simultaneous value creation, CWC stakeholders fulfill mutually beneficial interests such that their motivations, commitment, and trust in joint societal change initiatives are enhanced (Harrison, Bosse, \& Phillips, 2010). Consistent with our three-circle model, Figure 2 suggests that when the logics underlying each stakeholder category interact, joint interests have the capacity to create different types of wealth-social, economic, and communal wealth. Civic wealth is created when these three converge.
Social wealth creation. Social wealth is created at the intersection of Community and Regimes of Support. Here, needs arise in challenged civic settings or among groups with a common fate that are not addressed by market mechanisms, or that fall beyond the reach of effective government remedies (Mintzberg, 2015). These situations may be extreme and dire-war, natural or man-made disasters, starvation, chronic health conditions, etc.-or simply depressed and deteriorated-loss of jobs, increases in crime, ineffective education, crumbling infrastructure, air pollution, etc. In all of these cases, demoralization and lack of power often impede a community from changing these conditions (Narayan-Parker \& Patel, 2000), leaving community members unable to make substantial progress or facing threats to their sense of identity and belonging.

Under these circumstances, social wealth can be created in several ways. When members of a community, animated by the logics of kinship and citizenry, request assistance or backing from Regimes of

FIGURE 2

\section{Civic Wealth Creation Framework}

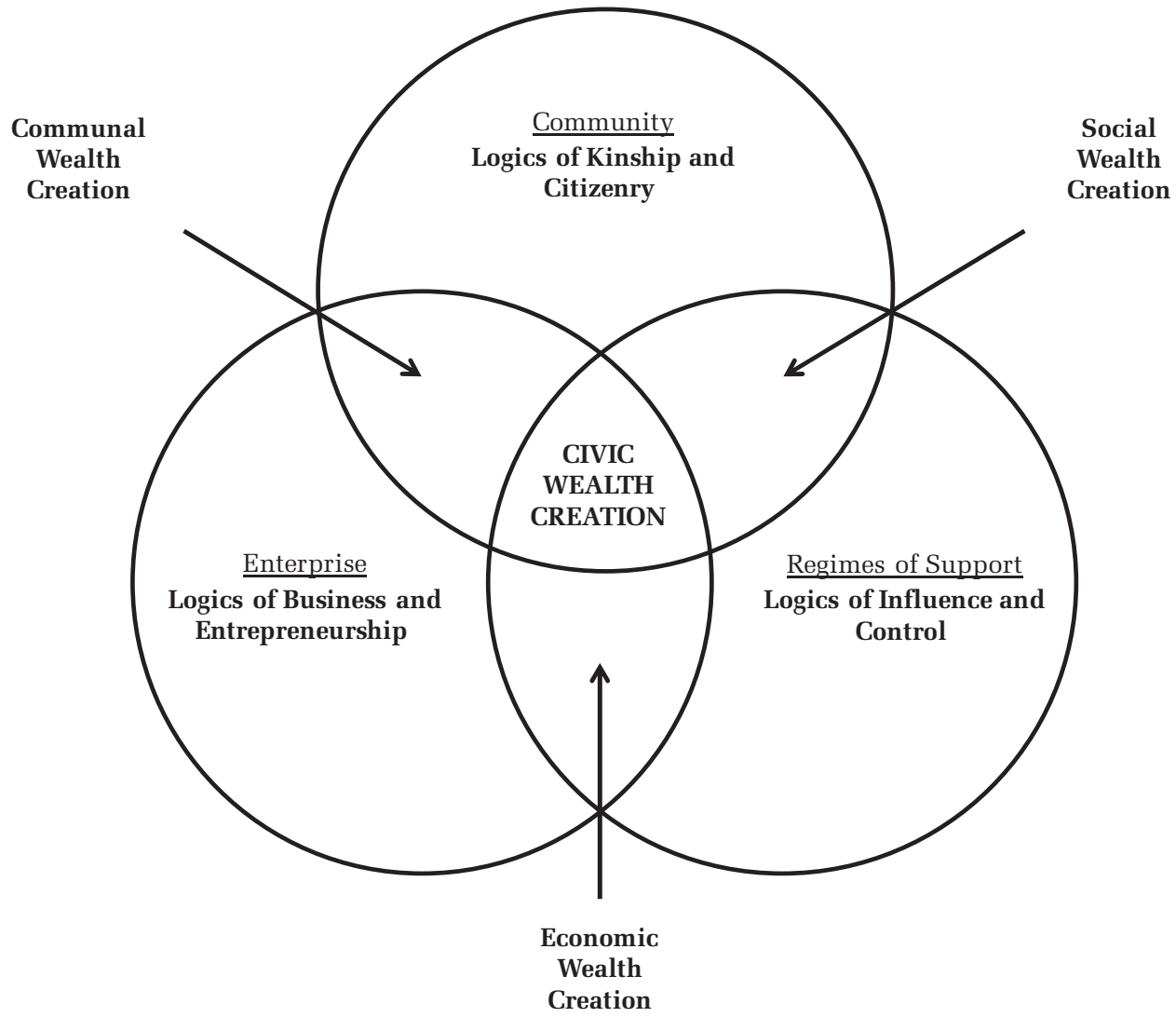


Support members, bottom-up development can incrementally strengthen social capital and build capacity (Woolcock, 1998). Alternatively, outsiders recognizing the needs of a community may step in without being formally asked to offer resources and assistance to boost a community's well-being in a top-down fashion (Woolcock, 1998). Outside-in development approaches, in which society invests in and supports community members, especially children, is another avenue for creating social wealth (Worthman, 2011). Regimes of Support stakeholders intervene in these situations because they are motivated to use their resources and talents to positively influence conditions surrounding a local populace (Hall, 2006). By so doing, there is an assumption that the returns from intervening and investing in a community will accrue to the benefit of society generally, according to the principles of inside-out development (Worthman, 2011). In these and other ways, across a variety of civic settings, interactions between the logics of kinship and citizenry and the logics of influence and control stimulate social wealth creation.

Economic wealth creation. The logics of business and entrepreneurship propel enterprises to pursue economic wealth through commerce. The business models that drive these activities account for the value-adding processes that generate cash flow, but they typically do not address how economic wealth is accumulated. For example, a new venture without an accumulated stock of resources often needs outside funding to expand and grow. For that, it often turns to external sources of support. Although it may negotiate terms, a new venture usually accepts supporters' demands because it benefits from the financial infusion. Funding may also be accompanied by other support, such as professional management skills and legal advice (Gompers \& Lerner, 2001), networking and social capital (Batjargal \& Liu, 2004), and in-kind resources (Gazley, Chang, \& Bingham, 2006), all of which can boost a venture's effectiveness and expand its reach. Providers of financial supportwhether in the form of a loan, an equity investment, or a philanthropic grant-are guided by two principles: to positively influence outcomes by contributing resources that advance the mission, and to exercise a degree of control over how the funding is used.

When these logics interact, economic wealth is created. Thus, when the logics of business and entrepreneurship interact with the logics of influence and control, new ventures are launched or expanded, new solutions are innovated, and operations are scaled. Financial supporters invest in such activities to share in the returns. Even in cases where ventures obtain financial support just to sustain financial viability, it fosters ongoing economic wealth creation. Legislators who pass laws enabling economic development or promoting commerce (Rappaport, 1999) and universities that provide expertise or inkind support to leverage the knowledge they create also do so in part to generate economic wealth (Shane, 2004). Through a variety of stakeholder combinations in different contexts, interactions between the logics of business and entrepreneurship and the logics of influence and control converge in the interest of economic wealth creation.

Communal wealth creation. As different as they are, the first two types of wealth creation-social and economic-are familiar, especially in the United States, where charitable giving aimed at supporting societal impact is greater than in any other country (Gaudiani, 2010), and where the capitalistic system places a premium on the financial gains that can be made by investing in profitable ventures (Dillard, 1987). However, a third kind of wealth is created when Community logics interact with Enterprise logics (Dubb, 2016). When members of a community join forces to improve their lot by forming a purposeful enterprise, it generates wealth that we characterize as "communal." Communal wealth is analogous to the wealth created when family members coalesce to create a family business (Berrone, Cruz, \& Gómez-Mejía, 2012).

Communal wealth creation derives from a diversity of needs and goals (e.g., overcoming poverty, raising living standards) that a community may aspire to address. The bonds of physical proximity or shared experiences in a community give its members a sense of kinship and citizenry that prompts them to act cohesively on their own behalf. The result is efforts such as community-based entrepreneurship, defined as "a community acting corporately as both entrepreneur and enterprise" (Peredo \& Chrisman, 2006, p. 310). Essential elements in this type of venture, they assert, are "communal values and the notion of the common good" (Peredo \& Chrisman, 2006, p. 323).

Enterprises provide economic activity around which community members can coalesce. They enable community members to prosper by focusing their creative energy and economic aspirations. Community-based ventures also provide settings for cultural enrichment, relationship building, and social interactions (Bacq \& Alt, 2018). An example is 
veterans creating employment systems adapted to the needs of veterans with disabilities, for whom job opportunities are rare because specialized work systems are deemed unprofitable for the private sector and too costly for government. Such qualityof-life improvements empower entire communities, and the financial sustainability they afford enhances self-reliance. Communal wealth is created when the logics of business and entrepreneurship interact with the logics of kinship and citizenry.

Civic wealth creation. Civic wealth is created when the logics underlying Community, Regimes of Support, and Enterprise coalesce to advance initiatives that improve the well-being of a given populace. Many communities are isolated from the production capabilities and resources needed to successfully undertake projects such as new ventures, empowerment projects, or local revitalization. For such stakeholders in the Community category, the support and experiences of other stakeholders are essential for them to flourish, at least initially. Regimes of Support can bestow legitimacy and augment progress through funding and networking. In turn, ventures and commercial activity in the Enterprise category foster self-reliance and financial viability, enabling communities to use their innate creativity and problem solving to thrive economically. For instance, social entrepreneurship emerged in part because disadvantaged communities needed a boost-an entrepreneurial boost. What makes CWC different from traditional aid or corporate social responsibility models is collective action through the integration of multiple stakeholders with different logics, including those who are direct beneficiaries of the effort. CWC addresses situations where the societal change initiatives that are being tackled are more complex than marketplace, government, or civil society solutions alone can effectively address.

\section{PARTIAL MODELS OF CIVIC WEALTH CREATION}

In the previous sections, we addressed CWC in a way that describes a sort of ideal type in which all three stakeholder categories overlap to generate relatively large and balanced amounts of social, economic, and communal wealth (see Figure 2). However, our framework is by nature dynamic, depending on stakeholders' intentions and involvement in CWC processes. Although in many cases all three stakeholder categories are well invested in creating social, economic, and communal wealth, there are other examples where only a portion of the potential stakeholder categories affecting or affected by a societal change participate in generating civic wealth. These "partial" models of CWC, as represented in Figure 3, reflect the idea that CWC can also be moderate (i.e., high in two types of wealth creation, low in one type of wealth creation) or weak (i.e., high in only one type of wealth creation, low in two types of wealth creation).

For instance, KaBOOM! is a nonprofit that combines community leadership with corporate donations and volunteers to build playgrounds (Leonard, Epstein, \& Winig, 2005), which contributes to revitalizing neighborhoods and invigorating communities. By engaging citizens and establishing connections between corporate sponsors and deprived communities, KaBOOM! is clearly creating civic wealth. Communal wealth is created as the communities' entrepreneurial drive and sense of responsibility increase. Social wealth is created as the communities benefit from improved playground facilities and accompanying benefits (e.g., healthier and more active kids, reduced crime rate). Yet economic wealth creation by KaBOOM! is relatively limited. Corporate partners fund most of the playground building costs but do not generate new or ongoing economic wealth creation. As such, KaBOOM! improves the locality but does little to contribute to its economic self-sufficiency, thus creating a moderate amount of civic wealth.

Another example is TOMS, the for-profit social enterprise known for donating one pair of shoes for every pair it sells. TOMS has furthered its "one-forone" business model for improving lives by also providing prescription glasses, sight-saving surgeries, clean water systems, safe birth kits, and bullying prevention services to people in need. As such, TOMS is generating wealth in dozens of communities around the world; the essence of its contribution lies in both economic wealth creation through high profits and social wealth creation through its donation programs (Stock, 2014). However, TOMS has been harshly criticized for fostering an ineffective form of philanthropy because it provides handouts in a patronizing manner (Short, 2013); because communities of beneficiaries have little or no involvement in its commercial activities, TOMS's communal wealth creation is seen as quite limited. As such, TOMS also generates only a moderate amount of civic wealth.

The microconsignment model (Van Kirk, 2010) is another example in which two types of wealth creation-economic and communal-combine with lower amounts of the third type, social wealth 
FIGURE 3

\section{Partial Models of Civic Wealth Creation}

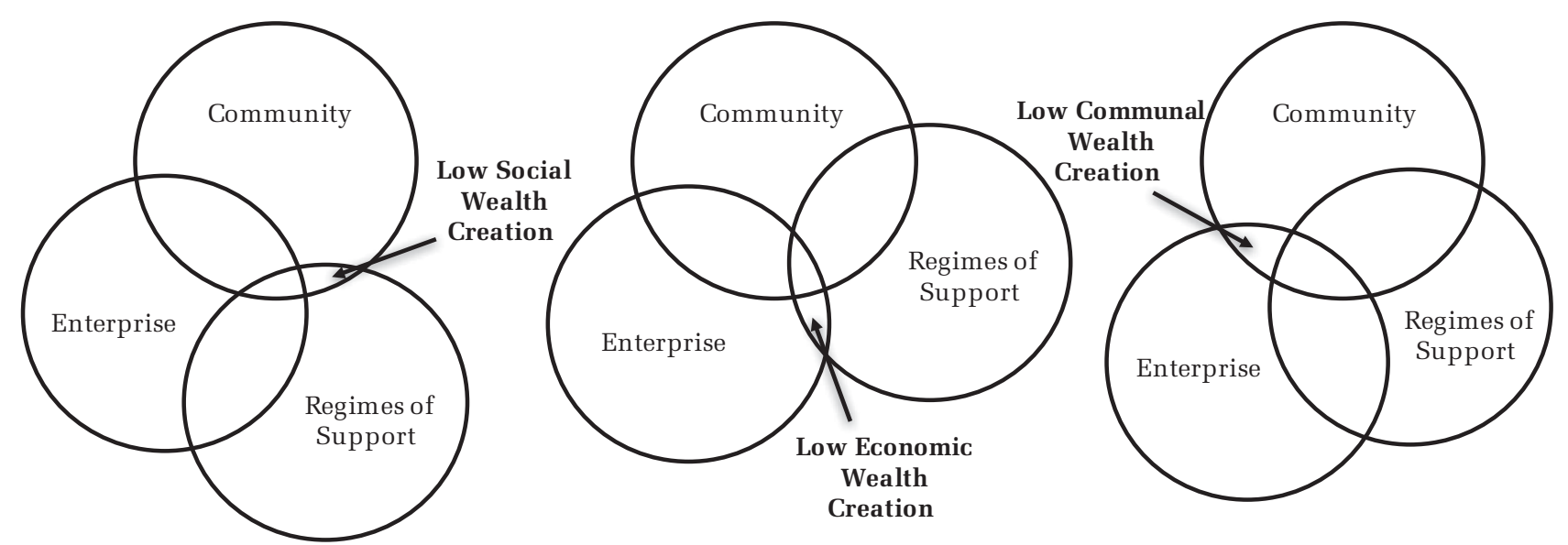

Low Social Wealth Creation High Economic Wealth Creation High Communal Wealth Creation
High Social Wealth Creation

Low Economic Wealth Creation

High Communal Wealth Creation
High Social Wealth Creation High Economic Wealth Creation Low Communal Wealth Creation creation. The model supports the development of micro-entrepreneurs, mostly women, to sell woodburning stoves, water filters, energy-efficient light bulbs, and other life-improving products to fellow villagers to generate income in rural localities where few opportunities exist to earn a living. The enterprises emerging from the microconsignment model link community members with the financial backing and resources of Regimes of Support to generate household income through commercial activity (economic wealth) and to foster self-sufficiency and build local capacity (communal wealth), both of which strengthen the whole community. This focus on micro-entrepreneurship is vital for community development but produces only modest amounts of social wealth, thus creating an overall moderate amount of civic wealth.

Last, there are examples such as Walmart that make valuable contributions to local communities but generate minimal amounts of CWC. With Walmart, the interaction between the Enterprise and Regimes of Support logics creates a high degree of economic wealth. Although jobs are created when it opens a new store, Walmart also has a reputation for reducing overall employment by putting local enterprises out of business (Neumark, Zhang, \& Ciccarella, 2008). Walmart does little to engage the Community in decision making or empower it to be more self-sufficient. Thus, the amount of communal wealth Walmart creates is relatively low. Further, the social interactions between Walmart and community members is rarely transformational and tends to be limited to small contributions such as sponsorships, thus generating relatively low degrees of social wealth. Overall, Walmart deserves credit for boosting economic wealth, but it creates only weak degrees of civic wealth. Table 1 summarizes and illustrates the various combinations of wealth creation leading to weak, moderate, and strong degrees of CWC.

Other factors may also contribute to strong, moderate, or weak degrees of CWC. For one, the distinctions among social, economic, and communal wealth may be more blurred in practice than our framework indicates, suggesting that other combinations of wealth are possible in any given situation. This point highlights the inherent messiness of a process as complex and layered as CWC. Further, efforts to create one type of wealth may supersede or affect the form and strength of other types of wealth creation. For example, CWC initiatives are likely subject to the type of mission drift that can cause projects to shift away from their societal focus in favor of economic demands (Jones, 2007). Finally, even in situations where a stakeholder coalition aims to create civic wealth, difficulties such as low 
TABLE 1

Strong/Moderate/Weak Degrees of Civic Wealth Creation

\begin{tabular}{|c|c|c|c|c|}
\hline $\begin{array}{c}\text { Degree of civic } \\
\text { wealth creation }\end{array}$ & $\begin{array}{l}\text { Social wealth } \\
\text { creation }\end{array}$ & $\begin{array}{c}\text { Economic wealth } \\
\text { creation }\end{array}$ & $\begin{array}{c}\text { Communal wealth } \\
\text { creation }\end{array}$ & Examples \\
\hline Strong & High & High & High & Mondragón, Housing Works Water for People \\
\hline & High & Low & High & КаBOOM! \\
\hline & Low & High & High & Microconsignment Model \\
\hline Weak & High & Low & Low & Soup kitchen \\
\hline
\end{tabular}

commitment by participants, ineffective collaboration, and lack of resources may impede or complicate efforts, leading to dysfunctional or suboptimal outcomes. In such cases, partial CWC may be the norm rather than the exception. To address ways to optimize outcomes, we turn next to CWC mechanisms.

\section{MECHANISMS OF CIVIC WEALTH CREATION}

How do multiple stakeholders with joint interests create civic wealth? Building on prior research in adjacent fields, we identify three mechanisms that stakeholders use to catalyze CWC: engaged participation, collaborative innovation, and resource mobilization.

\section{Engaged Participation}

Engaged participation is the mechanism that enables multiple stakeholders to become committed to CWC. In our framework, two aspects of participation contribute to CWC. The first is engaging community members in every phase of social venturing, from conceiving and designing solutions to organizing, building, and maintaining enterprises. Decades of research across a range of disciplines has shown that trying to help beneficiaries without involving them in developing remedies, or handing off solutions to communities without their participation and buy-in, is very likely to end in failure, negating the efforts and perhaps even diminishing the situation (e.g., Haines, 2008). By contrast, high levels of engagement provide an important mechanism for empowering community members to take ownership of the wealth they are creating and to take initiative in creating new wealth (Bovaird, 2007). Studies of asset-based community development (Kretzmann \& McKnight, 1996) and community-based enterprises (Peredo \& Chrisman, 2006) have highlighted the importance of drawing on local insights, resources, and capabilities for building community well-being and cumulating civic wealth.

Second, engaged participation involves commitment by key stakeholders who, by leveraging their talents and values, provide resources and legal authority (Regimes of Support) and entrepreneurial solutions (Enterprises) (Young, 2006). Di Domenico and colleagues found that "the active involvement of stakeholders in the creation, management, and governance" (2010, p. 695) of CWC-type initiatives was evident in every venture studied. Stakeholder theory emphasizes the types of mutual interactions that enable engaged stakeholders to improve quality of life and the sustainability of the natural world (Sachs \& Rühli, 2011). Engaged participation is vital for addressing the complexities involved in creating civic wealth.

\section{Collaborative Innovation}

Collaborative innovation-"the pursuit of innovations across firm boundaries through the sharing of ideas, knowledge, expertise, and opportunities" (Ketchen, Ireland, \& Snow, 2007, p. 371)-is also an important source of CWC. Social ills and societal disequilibria spur innovative activity that contributes to new social arrangements and systemic change (Alvord et al., 2004). In a civic context, the collaborative innovations that bring stakeholders together around societal change initiatives are typically interorganizational. Such collaborations generate new patterns of exchange among key players (Biggart \& Delbridge, 2004), such as philanthropic organizations funding a private enterprise (Van Slyke \& Newman, 2006) and community bonding around an entrepreneurial venture (Tracey, Phillips, \& Haugh, 2005).

Insights from stakeholder theory help illustrate the importance of collaboration for CWC by focusing on how multiple stakeholders work together on initiatives that increase the well-being of society 
(Cabral, 2017). For example, by communicating and negotiating in ways that foster interactions among stakeholders, new points of agreement emerge, mutual trust is developed (Wicks, Gilbert, \& Freeman, 1994), stakeholders become more identified with the goals of the initiative (Scott \& Lane, 2000), and relationship-building is enhanced (Harrison et al., 2010). A recent analysis of multisector problemsolving collaborations (Savage et al., 2010) emphasized integrative strategies that promote cooperation among stakeholders and identified three factors that bestow collaborative advantages: a common sense of mission, power sharing and joint decision making, and supportive communication. Such factors help resolve disagreements among stakeholders who share a higher-order societal purpose but are driven by different logics.

\section{Resource Mobilization}

Harnessing and mobilizing various types of resources is nearly always critical for effective societal change (Nicholls, 2010). Given that resource constraints are an impediment to solving most societal problems (Desa \& Basu, 2013), research highlights how leveraging available resources is a centrally important mechanism around which multiple categories of stakeholders can coalesce for effective societal impact (Alvord et al., 2004; Austin et al., 2006; Haugh, 2007). Corner and Ho (2010) suggested that successful societal change often depends more on leveraging available resources than on pursuing an ideal solution. CWC opportunities provide a catalyst for obtaining resources (cf. Van de Ven, Sapienza, \& Villanueva, 2007).

Depending on the context, resource mobilization helps create civic wealth in various ways. Financial resources are essential to most CWC initiatives, but other types of resources-human, physical, and technological—are also critical (Haugh, 2007). On one hand, resources such as donated property, restored buildings, and funding can directly add to the stock of civic wealth in a community. On the other hand, resources such as volunteered hours, borrowed space, and leveraged professional networks can contribute to CWC by building cohesiveness and strengthening mutual interactions among categories of stakeholders. Fowler (2000) noted that mobilizing collaboration partners and other organizations engaged in societal transformation is itself critical for bringing about positive societal change. When CWC becomes a shared goal, it increases the incentives for multiple constituents to pool resources and fosters collaboration.

\section{DISCUSSION}

In this paper, we have defined CWC as the generation of social, economic, and communal endowments that benefit local communities, and provided a conceptual framework that explains how civic wealth is created across various civic settings. Next, we discuss how the CWC framework contributes to current understandings of wealth in relation to societal impact and social entrepreneurship. We then offer practical applications of the framework to new and existing societal change initiatives. Finally, we suggest several avenues for future CWC research.

\section{Conceptualizations of Wealth, Forms of Capital, and Social Entrepreneurship}

To begin, the CWC concept reflects a widening appreciation for wealth as something more than money and material possessions. For example, social wealth is used to suggest intangible outcomes such as happiness, life satisfaction, and social justice (Venkataraman, 2002; Zahra \& Wright, 2016), and socioemotional wealth captures the affective, noneconomic sense of fulfillment that comes from sharing and identifying with family system values (Berrone et al., 2012). Our analysis suggests that traditional, economic-centric conceptualizations of wealth are insufficient to capture the outcomes that many societal change initiatives are striving to achieve.

Second, our framework outlines how civic wealth is created when coalitions of diverse stakeholders intentionally pursue joint interests to achieve positive societal change. The three categories of stakeholders that contribute to wealth creation at the civic level correspond roughly to three major sectors of society: the business or private sector, the government or public sector, and civil society, often labeled the third or "plural" sector (Mintzberg, 2015). Although each is unique, there is clear crossover among the three. Stakeholders in the Enterprise category function like for-profit firms-managing revenues and expenses by focusing on efficient operations and financial sustainability-even though they may be organized as nonprofit organizations or cooperatives. Similarly, although Regimes of Support may include private-sector players such as corporations and wealthy families, they often contribute to CWC by leveraging government resources and public capabilities to enact societal change. Community represents segments of civil society that are both the target of and major players in CWC processes. 
Third, our framing of civic wealth as endowmentsthat is, aggregated resources and accumulated assets and capabilities-offers important possible extensions of the literature on types of capital (Anheier, Gerhards, \& Romo, 1995; Parsons, 1937, 1977) beyond tangible forms of wealth. Although it is common to think of capital as a factor of production or an input for creating wealth, in this context we focus on capital as an outcome of the CWC process. Furthermore, we find parallels between the four types of wealth created by CWC stakeholders-social, economic, communal, and civic-and four types of capital derived from the seminal work of Talcott Parsons (1937, 1977)—social capital, economic capital, cultural capital, and strategic capital (Groen, 2005; Groen, Wakkee, \& De Weerd-Nederhof, 2008). Specifically, social and economic capital clearly correspond to social and economic wealth. Cultural capital suggests the unique characteristics of human capital associated with communal wealth, as well as the shared experiences, artifacts, and traditions that build and preserve a community's identity. Finally, the strategic capital that is bestowed on a community with strong civic wealth enhances its ability to mobilize resources, exercise political power, and more effectively attain its civic-level goals. The idea of assessing levels and types of capital as a proxy for assessing wealth creation is promising for operationalizing and measuring the civic wealth concepts presented in this paper.

The idea that endowments are linked to different types of capital also highlights an important feature of CWC related to two concepts from the human development literature: 1) a capabilities approach, which addresses opportunities for experiencing outcomes such as emotional attachments, political choice, bodily health, and other qualities that are vital to human functioning (Nussbaum, 2001; Sen, 1985) and 2) capacity building, which refers to ongoing comprehensive efforts to strengthen the support systems and problem-solving resources of a community (Mattessich \& Monsey, 2004). On one hand, a capabilities approach focuses on providing access to the most basic types of resources needed to live well and function in society. Efforts such as providing food for the homeless or access to health care and education increase the capability of otherwise disadvantaged individuals to fulfill their potential. On the other hand, CWC focuses on capacity building, a common goal of many philanthropic efforts, which aims to enhance a community's ability to meet its own needs. For example, in the case of feeding the homeless, the emphasis is on gaining the resources and building the operational infrastructure to enhance the capacity of the community to provide its own meals. CWC represents an important type of capacity building because of its focus on generating self-sustaining initiatives.

The holistic approach to achieving societal change represented by the CWC framework arises in part because of the role that entrepreneurship has come to play in solving societal issues and achieving positive impacts. As an example, a key reason the Rescue Mission ${ }^{5}$ is able to serve nearly a quarter of a million meals per year to the homeless in Central New York is because of its 15 Thrifty Shopper stores that operate profitably and employ the homeless. Entrepreneurial commerce is central to their efforts to achieve positive societal impact. As we presented earlier, social entrepreneurship aimed at CWC can take many forms, including employee ownership of the means of production (Mondragón), health care coupled with gainful employment (Housing Works), and self-sufficient water and sanitation systems (Water for People). Although the details vary, what all variants of social entrepreneurship have in common is capacity building that creates endowments that accrue to the benefit of each civic setting.

Indeed, many social entrepreneurship examples include the components and actors that underlie CWC. In a social entrepreneurship context, civic wealth is created when entrepreneurial practices and business skills are employed to gather resources, generate commercial opportunities, foster selfemployment, and create operating efficiencies that strengthen communities and economically empower individuals within those communities. At the same time, not all societal change initiatives have strong entrepreneurial components, yet they still have the ability to contribute to CWC. Many types of CWC initiatives raise the standard of living and stimulate civic pride in a community but contribute only weakly to economic wealth creation. Other initiatives that are effective at building economic capabilities contribute only slightly to communal wealth creation. For example, giving a homeless person a meal may offer only a weak degree of CWC, while running a thrift shop to fund meals for the homeless may represent a moderate degree of CWC. However, by employing and training the homeless for jobs in the community, along with operating profitable thrift shops that fund services for the homeless, Rescue Mission illustrates a strong degree

\footnotetext{
${ }^{5}$ See www.rescuemissionalliance.org.
} 
of CWC. Thus, our integrative framework accounts for the full range of CWC, based on the extent to which all three types of wealth creation are engaged (see Table 1).

Last, by extending stakeholder theory to encompass social and communal wealth-creating activities in addition to economic wealth creation, our approach stresses the importance of stakeholder theory in contexts where the drive to achieve societal impact unites stakeholders around a common purpose. Rather than focusing on stakeholderrelated challenges faced by focal corporations, we apply stakeholder theory to societal problems facing communities and civic settings of all kinds. To do so, we have emphasized insights from stakeholder theory's principle of stakeholder cooperation to address the wealth that is created when stakeholders with joint interests interact (Freeman et al., 2010). This principle, although somewhat underdeveloped relative to other stakeholder theory themes, is a fundamental component of the theory (Bridoux \& Stoelhorst, 2016; Freeman, 1994) and is central to understanding how civic wealth is created.

\section{Practical Applications of the Civic Wealth Creation Framework}

Beyond its explanatory power, the usefulness of the CWC framework lies in implementing it in a civic setting. To illustrate this, we take the position of an outside facilitator who is invited to help implement a CWC process. Although in most cases a key stakeholder will initiate CWC, a stakeholder engaged in the process may have difficulty being objective-that is, understanding the situation from the perspective of other stakeholders. Therefore, a facilitator may be better equipped to understand the interrelated tasks of a complex civic-level solution.

The presence of a facilitator (e.g., a consultant) reflects a few other assumptions that are critical at the beginning of a CWC process. First, we assume that the definition of the problem is shared across stakeholder categories, and that the consultant recognizes that intentional action is needed for the change to be effective. Second, we assume that the multiple stakeholders have intersecting interests, and that even though their backgrounds and motivations may differ, they need to coalesce to bring about a civic-level solution. As an example, consider the situation at the beginning of the Mondragón phenomenon: a remote and economically disadvantaged region in a postwar period. No one part of society could have managed the transformation that followed, although each of the stakeholders would have had idiosyncratic ideas about how to proceed.

CWC anticipates multiple stakeholders joining forces to enact societal change. To engage all actors to take part in CWC, mapped in the three-circle model, the consultant needs to take several steps-although the process we outline is highly iterative and not necessarily linear. To start, it is important to get a sense of the community for which the change initiative is being developed. What are its wishes and beliefs? How can possible solutions support it, endow it, and strengthen its identity? As noted, imposed solutions that are insensitive to local conditions lack credibility and buy-in and inhibit the engaged participation needed to enact solutions. It is also important to take stock of the community's current endowments, resources, and capabilities, because these can often be leveraged in ways that generate effective solutions. Housing Works, for example, successfully tapped into the artist community that was empathetic to the HIV/AIDS crisis and also acutely aware of New York City's housing challenges. Appraising local endowments can also reveal nonmonetary types of wealth that can lead to further wealth creation-cultural, relational, environmental, historic, and so forth.

Next, the proposed solution to a civic problem may require resources and support that go well beyond current conditions. This point highlights two key roles played by a CWC consultant. One is to envision alternatives that local stakeholders may not be able to see because of their embeddedness in the situation they are attempting to remedy. The other is to find sustainable solutions rather than remedies that are temporary, politically expedient, or dependent on external support. This is the consultant's biggest challenge: to get the stakeholders to own the problem and, simultaneously, to think out of the box about how to solve it. Part of thinking outside the box is identifying the kinds of resources and support that will be needed beyond what is currently available. This is important because civic solutions typically involve more complex stakeholder maps with representatives from each category-Community, Regimes of Support, and Enterprise-who together contribute to solving different parts of the problem in a complementary fashion. For example, Water for People solutions are effective because villagers partner with teachers, entrepreneurs, technical specialists, civic leaders, and others-all of whom provide an array of funding, expertise, training, and accountability needed to make their hygiene systems 
work. Developing a network of engaged stakeholders is a critical success factor for CWC.

After all of these considerations, the task is to propose solutions and generate an action plan. The various logics that animate engaged stakeholders will be generative of new combinations and original thinking precisely because they represent different angles of vision. This principle highlights the importance of collaborative innovation wherein voices from all stakeholder categories engage in the conversation about remedies and solutions until they find answers that converge on their joint interests. It is an entrepreneurial process involving opportunity seeking, creative problem solving, and risk taking aimed at civic-level impact.

The next task is to convert these insights into a value proposition that can be examined for its viability and attractiveness. Along with meeting the needs inherent in the societal problem that is being addressed, the value proposition should also create benefits that exceed costs. CWC solutions are akin to sustainable enterprises where the norms of efficiency and effectiveness guide business operations. Depending on the specifics of the value proposition, the benefits that exceed costs may be tangible, intangible, or some combination of the two, but they are always appropriable-that is, they can accumulate and build to the advantage of the community. They turn into civic wealth.

Finally, the consultant has to grasp the actions or changes all parties to the agreement will need to make to actualize the plan, and effectively communicate that. Stakeholders may need to change old practices or make new commitments depending on the requirements of the action plan. Further, ongoing commitments and systems will be needed to sustain the solution-financial, cultural, relational, and political. Even after an agreement is reached and a plan is set forth, there will be periods of experimentation, discovery, and missteps that require that assumptions and plans be revisited and adjusted. That, plus the need to monitor activities, obtain feedback, and measure results will require ongoing attention to keep the wealth-creation processes fresh and viable.

These CWC processes undertaken by stakeholders from the three categories-from idea generation to consensus plan to implementation-are the activities that create civic wealth. Although different civic situations involve vastly different players and contexts, the activities are essentially the same. The CWC approach can be used as an intervention in an existing situation, or for finding new solutions. The results, as suggested by our different examples, include a range of civic wealth outcomes. For Mondragón, it was higher standards of living, lower unemployment, and economic stability; for Housing Works, lower reliance on charity and increased community and cultural engagement; for Water for People, improved health and safety and greater selfsufficiency. In all of these cases, the outcome was increased civic wealth.

\section{Future Research Opportunities}

The CWC framework, which encompasses a wide variety of societal change activities, offers many future research opportunities. For instance, CWC processes can be analyzed in terms of existing frameworks that have proven effective for analyzing civic-level phenomena, including 1) compassion organizing (Dutton, Worline, Frost, \& Lilius, 2006), which has been employed to understand the venture-creating activities that often emerge as a component of disaster recovery in local settings (Shepherd \& Williams, 2014), and, 2) prosocial organizing, an emerging idea for understanding CWC activities and motivations involving "enactments that cater to the welfare of other individuals, groups, or organizations" (Branzei, Parker, Moroz, \& Gamble, 2018). It is also important to note that, although this paper is written from the perspective of social helping and positive societal change in socially challenged situations, the CWC process can elevate already well-functioning communities to higher levels of health, well-being, and civic pride. CWC as an aspirational model for advancing communities of all types is a promising future research topic.

Future research is also needed to assess CWC effectiveness. In any given civic context, the amount of civic wealth created will vary as a function of the amounts of social, economic, and communal wealth that is created. While future researchers can gain insights using measures of noneconomic outcomes that have been proposed by a variety of parallel disciplines, including community development (Dorius, 2011), public administration (Cowling, 2006), and interorganizational cooperation (Ring \& Van de Ven, 1994), the novel conceptualizations of wealth that we have set forth, and the parallels to types of capital that we have drawn, also offer future research avenues on the societal change processes that lead to new wealth creation.

With regard to the processes suggested by this analysis, both the temporal dynamics of CWC (e.g., whether a CWC initiative is project-based or a 
going concern) and the forms of organizing that CWC initiatives can take (e.g., cooperatives, community development projects, public-private partnerships, etc.) could be the focus of future CWC research. Future researchers could also use CWC to analyze entrepreneurial efforts to create "new organizing assemblages" (Daskalaki, Hjorth, \& Mair, 2015, p. 420), in which "individuals and networks enhance their collective capacity by assembling active forces and directing them via new organization. Creative activities assemble local skills, capabilities, and networked/ digital relationships to build cultural-social values that are necessary for nurturing and maintaining community life."

Another challenge related to the CWC process revolves around differences in stakeholder logics. The strength of the logics animating stakeholders will likely vary within and across CWC initiatives. Weak logics may hinder stakeholders' voluntary actions to create civic wealth, whereas strong logics may facilitate them. For example, residents of a marginalized neighborhood may initially have only a weak sense of kinship and citizenry, inhibiting them from coalescing around an entrepreneurial project that

\section{TABLE 2}

Researching Civic Wealth Creation: Future Research Questions

Researching different key aspects of civic wealth creation

\section{CWC across contexts}

How does the breadth or the depth of the societal problem being addressed relate to the amount of civic wealth created?

How does the geographical location of a community (and, relatedly, the access to resources and technology) influence the amount of civic wealth created?

How does the extent of competition for resources affect CWC?

\section{Dynamics of CWC}

How do different configurations of the different kinds of wealth (social, economic, communal) relate to the amount of civic wealth created?

What are the temporal dynamics of CWC, if any?

How does the initial impetus or founding conditions of a CWC initiative (within a stakeholder category or at the intersection of two categories) affect the amount of civic wealth created?

\section{CWC and different forms of organizing}

In what ways do different forms of organizing contribute to CWC?

To what extent is the cooperative form a promising vehicle for CWC?

What are the contributions of new legal forms (e.g., B Corps, L3C, CIC) and enabling legislation to CWC?

\section{CWC and the strengths of logics}

Do the logics in each stakeholder category need to be of at least minimal "strength" to guarantee that purposeful action toward CWC is taken?

Do weak logics hinder CWC?

Are weak logics in one stakeholder category compensated for by strength in another stakeholder category?
Researching the mechanisms of civic wealth creation

\section{Engaged participation}

How does the Enterprise-Regimes of Support nexus effectively engage with the Community in which it is embedded to create civic wealth?

How do collections of people sharing common conditions and experiences raise support for their cause and attract entrepreneurs' attention to create civic wealth?

How do large corporations/universities better engender an entrepreneurial mindset among community members to create civic wealth?

Collaborative innovation

How do members of a neighborhood or village collaborate with an enterprise to acquire the entrepreneurial skills and creativity that will lift them out of poverty and create civic wealth?

How do Regimes of Support innovate solutions for populaces sharing common conditions or experiences but not the same geographical location? How do these efforts coalesce around entrepreneurial action to create civic wealth?

How do Enterprises creatively advocate for the cause of Community and join forces with Regimes of Support to create civic wealth?

\section{Resource mobilization}

What strategies do community enterprises use to attract resources from Regimes of Support stakeholders to create civic wealth?

Based on which criteria do impact investors/philanthropic organizations decide to commit resources to a social business/ nonprofit venture? Are these criteria the same in all cases? How do these criteria relate to CWC?

How do Enterprises and Regimes of Support pool their creativity and resources to better serve Communities in need of creating civic wealth?

\section{Multiplier effect and other possible mechanisms}

Does the concept of iterative loops accurately account for how stakeholders' mutual interactions transform into CWC?

Does CWC imply a multiplier effect?

Do Community, Regimes of Support, and Enterprise, through synergistic interactions, generate more social, economic, cultural, and strategic capital to be further reinvested in social entrepreneurship initiatives? 
creates civic wealth. Research also suggests that when cross-sector partners attempt collective action, differences in material interests during collaborations enact conflicts that can actually improve outcomes (Powell, Hamann, Bitzer, \& Baker, 2018), a finding with far-reaching implications for how CWC manifests. Such issues raise questions about power relationships, structural issues, and leadership that could spur fruitful future research.

Finally, investigating the ethical implications of CWC - which are linked to stakeholder theory and the term civic itself-could lead to new insights and future research opportunities. As presented here, CWC is centered on positive outcomes. However, funding and support provided in the name of CWC may not be motivated by prosocial aspirations or offered with high integrity but rather directed toward selfish or corrupt ends, or driven by aims such as dynasty building. In numerous international aid situations, there are stories of fraud and corruption alongside the good being done (Riddell, 2007). Ethical issues are also raised when CWC efforts unintentionally go awry (Dacin et al., 2010). Stakeholder theorists have always contended that interactions among stakeholders can become destructive (Freeman, 1984). Civic wealthcreating activities are not immune from such dangers. Unethical behaviors clearly undermine the positive change intentions inherent in such situations and represent an important topic for future research.

Other research questions related to the nature and context of the societal problems being addressed, the characteristics of and relationships among the stakeholders addressing them, and the mechanisms of CWC are among the possible future research questions we suggest in Table 2.

\section{CONCLUSION}

In this paper, we have proposed CWC as a broad category of societal change activities involving coalitions of local citizens intending to make civiclevel improvements. Our framework suggests that civic wealth is created when members of three stakeholder categories who are driven by distinctive logics of action-Community, Regimes of Support, and Enterprise-interact synergistically to generate positive societal change. As such, CWC goes beyond traditional views of societal impact to suggest a more holistic approach to understanding societal outcomes by integrating entrepreneurial commerce and the engagement of beneficiaries into societal change processes. When the joint interests and purposeful efforts of engaged stakeholders coalesce around a CWC initiative, communities prosper, long-standing structural issues are resolved, self-reliance grows, and civil society is strengthened.

\section{REFERENCES}

Alvord, S. H., Brown, L. D., \& Letts, C. W. (2004). Social entrepreneurship and social transformation: An exploratory study. Journal of Applied Behavioral Science, 40(3), 260-282.

Anheier, H. K., Gerhards, J., \& Romo, F. P. (1995). Forms of capital and social structure in cultural fields: Examining Bourdieu's social topography. American Journal of Sociology, 100(4), 859-903.

Austin, J. E., Stevenson, H., \& Wei-Skillern, J. (2006). Social and commercial entrepreneurship: Same, different, or both? Entrepreneurship Theory and Practice, 30(1), $1-22$.

Bacq, S., \& Alt, E. (2018). Feeling capable and valued: A prosocial perspective on the link between empathy and social entrepreneurial intentions. Journal of Business Venturing, 33(3), 333-350.

Barman, E. (2008). With strings attached: Nonprofits and the adoption of donor choice. Nonprofit and Voluntary Sector Quarterly, 37(1), 39-56.

Batjargal, B., \& Liu, M. (2004). Entrepreneurs' access to private equity in China: The role of social capital. Organization Science, 15(2), 159-172.

Berrone, P., Cruz, C., \& Gómez-Mejía, L. R. (2012). Socioemotional wealth in family firms: Theoretical dimensions, assessment approaches, and agenda for future research. Family Business Research, 25(3), 258-279.

Berrone, P., Gelabert, L., Massa-Saluzzo, F., \& Rousseau, H. E. (2016). Understanding community dynamics in the study of grand challenges: How nonprofits, institutional actors, and the community fabric interact to influence income inequality. Academy of Management Journal, 59(6), 1940-1964.

Biggart, N. W., \& Delbridge, R. (2004). Systems of exchange. Academy of Management Review, 29(1), 28-49.

Bollen, K. A., \& Hoyle, R. H. (1990). Perceived cohesion: A conceptual and empirical examination. Social Forces, 69(2), 479-504.

Bovaird, T. (2007). Beyond engagement and participation: User and community coproduction of public services. Public Administration Review, 67(5), 846-860.

Branzei, O., Parker, S. C., Moroz, P. W., \& Gamble, E. (2018). Going pro-social: Extending the individualventure nexus to the collective level. Journal of Business Venturing, 33(5), 551-565. 
Bridoux, F., \& Stoelhorst, J. W. (2016). Stakeholder relationships and social welfare: A behavioral theory of contributions to joint value creation. Academy of Management Review, 41(2), 229-251.

Bryson, J. M. (2004). What to do when stakeholders matter: Stakeholder identification and analysis techniques. Public Management Review, 6(1), 21-53.

Bryson, J. M., Crosby, B. C., \& Stone, M. M. (2006). The design and implementation of cross-sector collaborations: Propositions from the literature. Public Administration Review, 66(s1), 44-55.

Bugg-Levine, A., Kogut, B., \& Kulatilaka, N. (2012). A new approach to funding social enterprises. Harvard Business Review, 90(1/2), 118-123.

Cabral, S. (2017). Reconciling conflicting policy objectives in public contracting: The enabling role of capabilities. Journal of Management Studies, 54(6), 823-853.

Chisolm, L. B. (1995). Accountability of nonprofit organizations and those who control them: The legal framework. Nonprofit Management \& Leadership, 6(2), 141-156.

Chliova, M., \& Ringov, D. (2017). Scaling impact: Template development and replication at the base of the pyramid. Academy of Management Perspectives, 31(1), 44-62.

Corner, P. D., \& Ho, M. (2010). How opportunities develop in social entrepreneurship. Entrepreneurship Theory and Practice, 34(4), 635-659.

Cowling, M. (2006). Measuring public value: The economic theory. Lancaster, UK: The Work Foundation.

Dacin, P. A., Dacin, M. T., \& Matear, M. (2010). Social entrepreneurship: Why we don't need a new theory and how we move forward from here. Academy of Management Perspectives, 24(3), 37-57.

Daskalaki, M., Hjorth, D., \& Mair, J. (2015). Are entrepreneurship, communities, and social transformation related? Journal of Management Inquiry, 24(4), 419-423.

Dean, T. J., \& McMullen, J. S. (2007). Toward a theory of sustainable entrepreneurship: Reducing environmental degradation through entrepreneurial action. Journal of Business Venturing, 22(1), 50-76.

Dees, J. G. (1998). The meaning of social entrepreneurship. Kansas City, MO: Kauffman Centre for Entrepreneurial Leadership.

Dees, J. G., \& Anderson, B. B. (2003). For-profit social ventures. In M. L. Kourilsky \& W. B. Walstad (Eds.), Social entrepreneurship. Birmingham, UK: Senate Hall Academic Publishing.

Defourny, J., \& Develtere, P. (2009). The social economy: The worldwide making of a third sector. In J.
Defourny, P. Develtere, B. Fonteneau, \& M. Nyssens (Eds.), The worldwide making of the social economy: Innovations and changes (pp. 15-40). Leuven, Netherlands: Acco.

Desa, G., \& Basu, S. (2013). Optimization or bricolage? Overcoming resource constraints in global social entrepreneurship. Strategic Entrepreneurship Journal, $7(1), 26-49$.

Di Domenico, M., Haugh, H., \& Tracey, P. (2010). Social bricolage: Theorizing social value creation in social enterprises. Entrepreneurship Theory and Practice, 34(4), 681-703.

Dillard, D. (1987). Money as an institution of capitalism. Journal of Economic Issues, 21(4), 1623-1647.

Donaldson, T., \& Preston, L. E. (1995). The stakeholder theory of the corporation: Concepts, evidence, and implications. Academy of Management Review, 20(1), 65-91.

Dorius, N. (2011). Measuring community development outcomes: In search of an analytical framework. ECOnomic Development Quarterly, 25(3), 267-276.

Dubb, S. (2016). Community wealth building forms: What they are and how to use them at the local level. Academy of Management Perspectives, 30(2), 141-152.

Dutton, J. E., Worline, M. C., Frost, P. J., \& Lilius, J. (2006). Explaining compassion organizing. Administrative Science Quarterly, 51(1), 59-96.

Eisenhardt, K. M., \& Zbaracki, M. (1992). Strategic decision making. Strategic Management Journal, 13(S2), 17-37.

Ellerman, D. P. (1984). Entrepreneurship in the Mondragón cooperatives. Review of Social Economy, 42(3), 272-294.

Fisher, G. (2012). Effectuation, causation, and bricolage: A behavioral comparison of emerging theories in entrepreneurship research. Entrepreneurship Theory and Practice, 36(5), 1019-1051.

Fowler, A. (2000). NGDOs as a moment in history: Beyond aid to social entrepreneurship or civic innovation? Third World Quarterly, 21(4), 637-654.

Freeman, R. E. (1984). Strategic management: A stakeholder approach. Boston: Pitman.

Freeman, R. E. (1994). The politics of stakeholder theory: Some future directions. Business Ethics Quarterly, 4(4), 409-421.

Freeman, R. E., Harrison, J. S., Wicks, A. C., Parmar, B. L., \& De Colle, S. (2010). Stakeholder theory: The state of the art. Cambridge, UK: Cambridge University Press.

Friedman, M. T., \& Mason, D. S. (2004). A stakeholder approach to understanding economic development decision making: Public subsidies for professional sport facilities. Economic Development Quarterly, 18(3), 236-254. 
Gaudiani, C. (2010). Generosity unbound. New York: Broadway Publications.

Gazley, B., Chang, W. K., \& Bingham, L. B. (2006). Collaboration and citizen participation in community mediation centers. Review of Policy Research, 23(4), 843-863.

George, G., Howard-Grenville, J., Joshi, A., \& Tihanyi, L. (2016). Understanding and tackling societal grand challenges through management research. Academy of Management Journal, 59(6), 1880-1895.

Gompers, P., \& Lerner, J. (2001). The money of invention: How venture capital creates new wealth. Boston: Harvard Business School Press.

Gras, D., \& Mendoza-Abarca, K. I. (2014). Risky business? The survival implications of exploiting commercial opportunities by nonprofits. Journal of Business Venturing, 29(3), 392-404.

Groen, A. J. (2005). Knowledge intensive entrepreneurship in networks: Towards a multi-level/multi-dimensional approach. Journal of Enterprising Culture, 13(01), 69-88.

Groen, A. J., Wakkee, I. A., \& De Weerd-Nederhof, P. C. (2008). Managing tensions in a high-tech start-up: An innovation journey in social system perspective. International Small Business Journal, 26(1), 57-81.

Haines, A. (2008). Asset-based community development. In R. Phillips \& R. Pittman (Eds.), An introduction to community development (pp. 38-48). London: Routledge.

Hall, P. D. (2006). A historical overview of philanthropy, voluntary associations, and nonprofit organizations in the United States, 1600-2000. In W. W. Powell \& R. Steinberg (Eds.), The nonprofit sector: A research handbook (pp. 32-65). New Haven, CT: Yale University Press.

Harrison, J. S., Bosse, D. A., \& Phillips, R. A. (2010). Managing for stakeholders, stakeholder utility functions, and competitive advantage. Strategic Management Journal, 31(1), 58-74.

Haugh, H. (2005). Social enterprise: Beyond economic outcomes and individual returns. In J. Mair, J. Robinson, \& K. Hockerts (Eds.), Social entrepreneurship (pp. 180-205). London: Palgrave Macmillan.

Haugh, H. (2007). Community-led social venture creation. Entrepreneurship Theory and Practice, 31(2), 161-182.

Holland, M. (2012). Social bonding and nurture kinship: Compatibility between cultural and biological approaches. North Charleston, SC: Createspace Press.

Jones, M. B. (2007). The multiple sources of mission drift. Nonprofit and Voluntary Sector Quarterly, 36(2), 290-310.
Ketchen, D. J., Ireland, R. D., \& Snow, C. C. (2007). Strategic entrepreneurship, collaborative innovation, and wealth creation. Strategic Entrepreneurship Journal, 1(3-4), 371-385.

Kretzmann, J. P., \& McKnight, J. (1996). Assets-based community development. National Civic Review, 85(4), 23-29.

Lehner, O. M., \& Nicholls, A. (2014). Social finance and crowdfunding for social enterprises: A public-private case study providing legitimacy and leverage. Venture Capital, 16(3), 271-286.

Leonard, H. B., Epstein, M., \& Winig, L. (2005). Playgrounds and performance: Results management at KaBOOM! (A) (Case 306-031). Boston: Harvard Business School.

Lichterman, P., \& Eliasoph, N. (2014). Civic action. American Journal of Sociology, 120(3), 798-863.

Longhofer, W., Negro, G., \& Roberts, P. W. (2019). The changing effectiveness of local civic action: The critical nexus of community and organization. Administrative Science Quarterly, 64(1), 203-229.

Lumpkin, G. T., Bacq, S., \& Pidduck, R. J. (2018). Where change happens: Focusing on community-level phenomena in social entrepreneurship research. Journal of Small Business Management, 56(1), 24-50.

Lupton, R. (2012). Toxic charity: How churches and charities hurt those they help (and how to reverse it). New York: HarperOne.

Mair, J., \& Martí, I. (2006). Social entrepreneurship research: A source of explanation, prediction and delight. Journal of World Business, 41(1), 36-44.

Marquis, C., \& Park, A. (2014). Inside the buy-one give-one model. Stanford Social Innovation Review, 12(1), 28-33.

Mattessich, P., \& Monsey, M. (2004). Community building: What makes it work. St. Paul, MN: Wilder Foundation.

McMullen, J. S., \& Dimov, D. (2013). Time and the entrepreneurial journey: The problems and promise of studying entrepreneurship as a process. Journal of Management Studies, 50(8), 1481-1512.

Mintzberg, H. (2015). Time for the plural sector. Stanford Social Innovation Review, 13(3), 28-33.

Moyo, D. (2009). Dead aid: Why aid is not working and how there is a better way for Africa. London: Palgrave Macmillan.

Narayan-Parker, D., \& Patel, R. (2000). Voices of the poor: Can anyone hear us? Washington, DC: World Bank Publications.

Neumark, D., Zhang, J., \& Ciccarella, S. (2008). The effects of Wal-Mart on local labor markets. Journal of Urban Economics, 63(2), 405-430. 
Nicholls, A. (2010). The legitimacy of social entrepreneurship: Reflexive isomorphism in a pre-paradigmatic field. Entrepreneurship Theory and Practice, 34(4), 611-633.

Nussbaum, M. (2001). Women and human development: The capabilities approach. Cambridge, UK: Cambridge University Press.

Ostrom, E. (1965). Public entrepreneurship: A case study in ground water basin management (Doctoral dissertation). University of California, Los Angeles.

Ostrom, E. (1990). Governing the commons: The evolution of institutions for collective action. Cambridge, UK: Cambridge University Press.

Parsons, T. (1937). The structure of social action. Glencoe, IL: The Free Press.

Parsons, T. (1977). The evolution of societies. Upper Saddle River, NJ: Prentice Hall.

Peredo, A. M. (2003). Emerging strategies against poverty: The road less traveled. Journal of Management Inquiry, 12(2), 155-166.

Peredo, A. M., \& Chrisman, J. J. (2006). Toward a theory of community-based enterprise. Academy of Management Review, 31(2), 309-328.

Phillips, R. A., Freeman, R. E., \& Wicks, A. C. (2003). What stakeholder theory is not. Business Ethics Quarterly, 13(4), 479-502.

Powell, E. E., Hamann, R., Bitzer, V., \& Baker, T. (2018). Bringing the elephant into the room? Enacting conflict in collective prosocial organizing. Journal of Business Venturing, 33(5), 623-642.

Prahalad, C. K., \& Bettis, R. A. (1986). The dominant logic: A new linkage between diversity and performance. Strategic Management Journal, 7(6), 485-501.

Putnam, R. D. (2000). Bowling alone: America’s declining social capital. In L. Crothers \& C. Lockhart (Eds.), Culture and politics (pp. 223-234). New York: Palgrave Macmillan.

Rappaport, A. (1999). Creating shareholder value: A guide for managers and investors. New York: Simon and Schuster.

Riddell, R. C. (2007). Does foreign aid really work? Oxford, UK: Oxford University Press.

Ring, P. S., \& Van de Ven, A. H. (1994). Developmental processes of cooperative interorganizational relationships. Academy of Management Review, 19(1), 90-118.

Sachs, S., \& Rühli, E. (2011). Stakeholders matter: A new paradigm for strategy in society. Cambridge, UK: Cambridge University Press.

Sarasvathy, S. D. (2001). Causation and effectuation: Toward a theoretical shift from economic inevitability to entrepreneurial contingency. Academy of Management Review, 26(2), 243-263.

Savage, G. T., et al. (2010). Stakeholder collaboration: Implications for stakeholder theory and practice. Journal of Business Ethics, 96(1), 21-26.

Scott, S. G., \& Lane, V. R. (2000). A stakeholder approach to organizational identity. Academy of Management Review, 25(1), 43-62.

Sen, A. (1985). Commodities and capabilities. New York: North-Holland.

Shane, S. A. (2004). Academic entrepreneurship: University spinoffs and wealth creation. Cheltenham, UK, and Northampton, MA: Edward Elgar Publishing.

Shane, S. A., \& Venkataraman, S. (2000). The promise of entrepreneurship as a field of research. Academy of Management Review, 25(1), 217-226.

Shepherd, D. A. (2015). Party on! A call for entrepreneurship research that is more interactive, activity based, cognitively hot, compassionate, and prosocial. Journal of Business Venturing, 30(4), 489-507.

Shepherd, D. A., \& Williams, T. A. (2014). Local venturing as compassion organizing in the aftermath of a natural disaster: The role of localness and community in reducing suffering. Journal of Management Studies, 51(6), 952-994.

Short, K. (2013, November 14). Toms CEO Blake Mycoskie offers surprising answer to his critics. Huffington Post. Retrieved from https://www.huffingtonpost.com/2013/ 11/14/toms-ceo-critics_n_4274637.html

Stephan, U., Patterson, M., Kelly, C., \& Mair, J. (2016). Organizations driving positive social change: A review and an integrative framework of change processes. Journal of Management Studies, 42(5), 1250-1281.

Stewart, A. (2003). Help one another, use one another: Toward an anthropology of family business. Entrepreneurship Theory and Practice, 27(4), 383-396.

Stock, K. (2014, August 21). Bain Capital buys Toms, will still give away shoes. Bloomberg. Retrieved from https:// www.bloomberg.com/news/articles/2014-08-21/ bain-capital-buys-toms-the-625-million-do-goodershoe-company

Stott, N., Fava, M., Tracey, P., \& Claus, L. (2018, April). Playing well with others? Community cross-sector work in poor places. Paper presented at the Rethinking Cross-Sector Social Innovation Conference, Harvard Kennedy School.

Tantalo, C., \& Priem, R. (2016). Value creation through stakeholder synergy. Strategic Management Journal, 37(2), 314-329.

Tracey, P., Phillips, N., \& Haugh, H. (2005). Beyond philanthropy: Community enterprise as a basis for 
corporate citizenship. Journal of Business Ethics, 58(4), 327-344.

Van de Ven, A. H., \& Poole, M. S. (1995). Explaining development and change in organizations. Academy of Management Review, 20(3), 510-540.

Van de Ven, A. H., Sapienza, H. J., \& Villanueva, J. (2007). Entrepreneurial pursuits of self- and collective interests. Strategic Entrepreneurship Journal, 1(3-4), 353-370.

Van Kirk, G. (2010). The microconsignment model: Bridging the "last mile" of access to products and services for the rural poor. Innovations, 5, 101-127.

Van Slyke, D. M., \& Newman, H. K. (2006). Venture philanthropy and social entrepreneurship in community redevelopment. Nonprofit Management \& Leadership, 16(3), 345-368.

Venkataraman, S. (2002). Stakeholder value equilibration and the entrepreneurial process. In R. E. Freeman \& S. Venkataraman (Eds.), The Ruffin series no. 3: Ethics and entrepreneurship (pp. 45-57). Charlottesville, VA: Philosophy Documentation Center.

Walsh, J. P., Weber, K., \& Margolis, J. D. (2003). Social issues and management: Our lost cause found. Journal of Management, 29(6), 859-881.

Wicks, A. C., Gilbert, D. R., \& Freeman, R. E. (1994). A feminist reinterpretation of the stakeholder concept. Business Ethics Quarterly, 4(4), 475-497.

Woolcock, M. (1998). Social capital and economic development: Toward a theoretical synthesis and policy framework. Theory and Society, 27(2), 151-208.

Worthman, C. M. (2011). Inside-out and outside-in? Global development theory, policy, and youth. Ethos, 39(4), 432-451.

York, J. G., O’Neil, I., \& Sarasvathy, S. D. (2016). Exploring environmental entrepreneurship: Identity coupling, venture goals, and stakeholder incentives. Journal of Management Studies, 53(5), 695-737.

Young, R. (2006). For what it is worth: Social value and the future of social entrepreneurship. In A. Nicholls (Ed.), Social entrepreneurship: New models of sustainable social change (pp. 56-73). Oxford, UK: Oxford University Press.

Young, A., Russell, A., \& Powers, J. R. (2004). The sense of belonging to a neighbourhood: Can it be measured and is it related to health and well-being in older women? Social Science \& Medicine, 59(12), 2627-2637.

Yunus, M. (2008). Creating a world without poverty: Social business and the future of capitalism. New York: PublicAffairs.

Zahra, S. A., Gedajlovic, E., Neubaum, D. O., \& Shulman, J. M. (2009). A typology of social entrepreneurs: Motives, search processes and ethical challenges. Journal of Business Venturing, 24(5), 519-532.

Zahra, S. A., \& Wright, M. (2016). Understanding the social role of entrepreneurship. Journal of Management Studies, 53(4), 610-629.

Zott, C., \& Amit, R. (2007). Business model design and the performance of entrepreneurial firms. Organization Science, 18(2), 181-199.

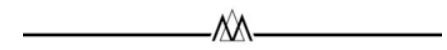

G. T. Lumpkin (lumpkin@ou.edu) is the Trosper Chair of Entrepreneurship and the Tom Love Entrepreneurship and Economic Development Division Director at the Price College of Business at the University of Oklahoma. He received his Ph.D. from the University of Texas in Arlington. His research interests include entrepreneurial orientation, social entrepreneurship, and family business.

Sophie Bacq (bacqs@iu.edu) is an associate professor of entrepreneurship at the Kelley School of Business at Indiana University. She received her Ph.D. from the Université catholique de Louvain. She investigates and theorizes about entrepreneurial action aiming to solve intractable social and environmental problems at the individual, organizational, and civic levels of analysis.

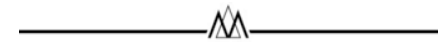


Copyright of Academy of Management Perspectives is the property of Academy of Management and its content may not be copied or emailed to multiple sites or posted to a listserv without the copyright holder's express written permission. However, users may print, download, or email articles for individual use. 